\title{
Ethics Inclusion in Accounting Learning: Establishing a Convergence Model of Education Stakeholders According to International Federation of Accountants
}

\author{
Muhammad Iqbal $^{1}$, Andi Chairil Furqan ${ }^{1, *}$, Nurlaela Mapparessa ${ }^{1}$, Tenriwaru ${ }^{2}$ \\ ${ }^{1}$ Department of Accounting, Universitas Tadulako, Palu, Indonesia \\ ${ }^{2}$ Department of Accounting, Universitas Muslim Indonesia, Makassar, Indonesia
}

Received August 6, 2019; Revised September 4, 2019; Accepted September 15, 2019

Copyright $\bigcirc 2019$ by authors, all rights reserved. Authors agree that this article remains permanently open access under the terms of the Creative Commons Attribution License 4.0 International License

\begin{abstract}
This paper aims to know the extent of ethics learning in accounting education including the role of education institutions, faculty and accounting students in order to support the effectivity of ethics learning. Research finding based on literature study method discovers the effectivity of ethics learning which indicated by students perceive about the importance of ethics behaviour that contributes to their attitude in accounting practices and then it also effects to their professionalization and responsibility. In addition the curriculums and learning facilities of education institutions, perceive and ethics training of faculty, working experiences, extrinsic motivation and student knowledge also influence to the effectivity of ethics learning. The limitation of this research is the method of research which only use literature study so that the forward research suggest to use other research method as survey, lab study or case study to produce empirical research.
\end{abstract}

Keyword Accounting Education, Ethics Learning, Educational Institution, Faculty, Accounting Student

\section{Introduction}

Accounting plays a key role in the social and economic development of a nation. Investors, creditors, and other stakeholders rely on the integrity of accounting information, especially those presented in the financial statements of an entity, including the company. Ethics is a factor that cannot be separated from the accounting profession, this can be seen as the purpose of accounting education which is directed to produce professional, competent and ethical accountants, so that it can benefit the profession and society (IFAC, 2005). Regarding ethics in accounting education, The International Federation of Accountants (IFAC) has issued International Education Standards (IES) 4 on Values, Ethics and Professional Attitudes (IFAC, 2005). In these standards, it is stated that educators must distinguish between teaching students/students about values, ethics and professional attitudes and teaching students/students about how to develop ethical behavior. The development of professional values needs to be carried out from the beginning of the education process and must be emphasized as part of lifelong learning.

Learning ethics is learning basic knowledge to support critical thinking, tolerance for diversity, and developing a system of responsibility for informal decision making. In addition, learning about ethics is also an effort to achieve intellectual power to distinguish facts, principles and priorities. Therefore educators should approach an ethical approach with a broad goal of developing sensitivity and intelligence to make correct decisions (IFAC, 2006). Educational institutions have the responsibility to facilitate students in developing two main competencies, namely ethical and technical competencies. Technical competence itself will not be effective in realizing ethics into practice if it is not accompanied by awareness and expertise to regulate different contexts (Fakhimuddin, 2018). Educational programs must consider learning contextual factors such as values, ethics and professional attitudes.

Today, despite the tremendous interest in learning about ethics, there are various kinds of dubious attitudes that are not even sure about the effectiveness of learning about ethics in accounting education, so it is still found that although learning about ethics has been conducted in accounting education, the majority of accounting education providers do not give priority great in learning about ethics. This happened because the education program only concentrated on accounting technical learning only and the 
lack of clarity in the academic validity of ethics in accounting. In fact, in terms of perceptions of the urgency of learning ethics in accounting education, Velliaris et al. (2015), Tormo-Carbó et al. (2016) found that there were differences in perceptions between students and teaching staff on the importance of learning about ethics in business and accounting where student perceptions of learning about ethics were more important than the perceptions of teaching staff. This is also supported by Martinov-Bennie and Mladenovic (2015) who found that students have more positive responses to learning about ethics in accounting education, where students believed that ethics courses would influence how they would act in the future (see also, Shawver \& Miller, 2017). This shows that although learning about ethics is an initiative that comes from educational institutions and educators, it turns out that in business education and accounting both educational institutions and educators have not been effective in conducting such learning about ethics. Regarding the effectiveness of learning ethics in an accounting education institution, Seele (2016), Jonson et al. (2016) recommend that these efforts not only be determined by students, but also require full support from education providers and educators especially in determining curriculum, ethics training for educators, objectives and tools provided to support learning about ethics. However, some research found that learning methods play an important role in mediating the influence of students' initial knowledge and educational technology on student competencies (Gaviria et al., 2016; Pan \& Seow, 2016; Lai \& Hong, 2015; Lawson et al., 2015). Hence, this article aims to explain the extent of the urgency of learning ethics in accounting education, what is the role of institutions education, teaching staff (lecturers/teaching staff) and accounting students in effective learning of ethics, and whether learning about ethics methods play an important role in realizing the effectiveness of learning ethics in accounting education.

\section{Literature Review}

\subsection{Ethics and Behavior}

International Education Standards (IES) 4 (IFAC, 2005) describe values, ethics and professional attitudes for professional accountants. Professional values, ethics and attitudes in question are behaviors and characteristics of professionals who can identify professional accountants as part of members of the profession, including actions that are associated with ethical principles that are considered important in defining different professional behavior and commitment to technical competence., ethical behavior (such as: independence, objectivity, confidence, and integrity); professional attitudes (such as: timeliness, politeness, respect, responsibility and trust), self-development efforts (such as commitment to sustainable development and lifelong learning) and social responsibility (such as: awareness and consideration of the public interest).

The principle of ethics is the basis or principle that becomes the basis of thinking regarding the truth and mistakes that are embraced by a society. Rest (1983) in IFAC (2006) states that ethical behavior is the result of four very related components, namely: (1). Moral sensitivity (awareness and interpretation); (2). Moral assessment (ability to make decisions to determine right and wrong); (3). Moral motivation (prioritizing moral values); and (4). Moral character (courage, perseverance and strength of character). Moral assessment is one type of normative assessment, while normative assessment is a belief about whether something is good or bad, right, wrong, what should be and what should not be done (IFAC, 2006). It reflects personal values and beliefs about an action, or response to a situation. In this regard, Lawrence Kohlberg (1960) in IFAC (2006) concludes that there are 6 (six) stages of development regarding a person's ability to deal with moral problems. Kohlberg (1981) groups these stages of development into 3 levels, each of which consists of 2 (two) stages. The six stages are as follows:

I. The Pre-Conventional level with its main motivation is self-interest.

- $\quad$ Stage 1: Penalty-oriented and obedient, where the right action is taken to avoid punishment.

- $\quad$ Stage 2: Instrument-oriented and relative, in which an individual, although aware of the interests of others, pursues action only as a means to satisfy the needs or desires of his own individual.

II. Conventional levels with the main impetus are to maintain relationships between people.

- Stage 3: Oriented to interpersonal harmony, where individuals try to satisfy the expectations of others.

- $\quad$ Stage 4: Law and order oriented, where individuals maintain a social system that has been determined by the law and social system of an authority or state.

III. The Post-Conventional Level is a level that is independent and based on principles;

- $\quad$ Stage 5: Oriented to social agreements, in which individuals who hold a variety of views and opinions, are emphasized in correct ways to reach consensus through agreement, agreement, and through the process. All values and norms are relative and should be tolerated.

- Stage 6: Oriented to the principles of universal ethics, where the right actions can be defined in terms of principles that can be generally accepted because of the logical understanding, generality and consistency. These ethical principles are not concrete, but are general principles that are abstract, related to justice, public welfare, equality of the human race and respect for others. 
Kohlberg's (1981) moral reasoning theory above is very important, because this theory helps understanding how individuals develop their moral abilities through "internalizing" the moral standards of a society. This also explains how one can become more critical and increase his understanding of the problem of moral standards. Although estimating a person's value or normative judgment may change with the development, but by trying, such as getting used to thinking, evaluating, and analyzing someone can develop a consensus on moral standards that can be applied consistently in society.

Aristotle's view of ethics described that ethics is impossible to determine exactly how humans must act. The ethics task is not to provide a list of questions that can be carried out as if with your eyes closed, but provides a kind of vision and perspective (see for instance, Aristotle, 2006). The person who has that perspective will find out how he acts in concrete situations. That perspective is called "proper understanding". Acting ethically means acting according to the right understanding. However "proper understanding" is not a measurement that is decomposed, but rather an inner attitude or sharpness of ethical reason to understand which actions are in the most appropriate situations. What in this case is "sharpening the taste and mind" is a must. Only because that is how to be properly understood human can be achieved.

\subsection{Learning about Ethics}

One important factor for developing one's moral awareness is education (Kohlberg, 1983 in IFAC, 2006). Education is an important factor in moving a person's moral awareness from one level to the next. Based on Kohlberg's theory, Salam (2000) argues that in the process of developing moral reasoning the following arguments apply:

a. Moral development occurs sequentially from one stage to the next.

b. In moral development, people cannot understand the way of thinking from more than two stages above.

c. In moral development, a person is cognitively attracted to ways of thinking from one stage above his own stage.

d. In moral development, development will only occur if a cognitive disequilibrium is created in students.

Based on the above arguments, it can be said that education is an important factor in moving one's moral awareness from one level to the next. Educational interventions on ethical issues can be effectively applied in improving certain aspects of moral choice of students starting from the beginning to the end of the semester (Ritter, 2006; Rutherford et al., 2012; Mladenovic et al., 2019). In general, Rest (1986) in IFAC (2006) claims that moral or ethical education programs are effective in supporting the development of moral judgments, especially if the program runs more than 3 weeks and the intervention involves participants in discussions about controversial moral dilemmas. The process of interactive exchange of opinions from students combined with solving moral problems will accelerate the development of natural moral judgments. The results of IFAC (2006) research concluded that ethical education should be introduced as part of a broader education program to develop the values, ethics and attitudes of professional accountants. Good ethical education means requiring students to think critically before making decisions that have ethical implications.

\section{Methodology}

The method of this research is an exploration study, which is a study directed at developing concepts more clearly, setting priorities, developing operational definitions and improving the final design of research (Sekaran \& Bougie, 2016). The conduct of this exploration research is to be able to comprehensively reveal the relevance of educators, educational institutions and accounting students to the effectiveness of learning about ethics in accounting education. In this study, an exploration of secondary data analysis techniques was carried out, namely conducting an analysis of several study results or articles from previous research both published in journals, presented at seminars/symposiums and unpublished. It is hoped that from this exploration can find a comprehensive solution in effective learning of ethics in accounting education.

\section{Learning about Ethics in Accounting Education}

According to Fiolleau and Kaplan (2017) accounting students need to be introduced to the factors that influence the making of ethical decisions and it will open opportunities for students to discuss ethical issues with students who have other ethical orientations. Ethics and moral competence are important characteristics in the accounting profession, and accounting education is part of the process of developing these competencies. Criticism of the accounting profession that questions the competence and integrity of its members is a major factor that increases the need for ethical education. Sims and Sims (1991) mention several reasons that make ethical issues need to be included in the business education curriculum (see also, Sauser Jr \& Sims, 2018), namely as follows:

a. Pressure that comes from outside professional organizations with the hope that accounting graduates behave better in their professional lives.

b. Certain moral issues, such as whistle-blowing and insider trading, students may one day need direction on the issue. 
c. Multidisciplinary changes and methodologies in educational programs that are only dominated by technical problems or qualitative components.

d. Scientific interests in issues of professional ethics can stimulate greater interests with learning about ethics.

In this regard, it is implied that business education needs to be directed at understanding ethics. Wymer and Rundle-Thiele (2017), Fernández and Sanjuán (2010), Wright and Bennett (2011) discussed the ethical emphasis in the application of various business fields caused an increase in concern in various business sectors, and this also resulted in increasing demand for education and ethics training in business education. Discussion of intensive ethical education should follow the development of the latest companies and also the crises that occur in the world of accounting. That is what emphasizes the importance that business education institutions include learning about ethics for accountants and future leaders (Shawver \& Miller, 2017; Mohd Ghazali, 2015).

Furthermore, based on the results of previous studies, IFAC (2006) concluded several objectives in studying ethics in business education, especially accounting, namely as follows:

a. Establish an intellectual foundation to understand the position of ethics.

Ethics education makes students able to reach an understanding and appreciation of the role of accounting, especially its responsibility to the wider community. Accountants must understand the political, economic and social implications of the accounting profession and structural problems that hinder ethical decision making and have a sense of moral obligation to society.

b. Develop Ethical sensitivity.

Empirical evidence shows that the average accountant's ethical awareness is still low, which is why it needs to develop ethical sensitivity, so that it can avoid ethical behavior. For this reason, ethics education will make students more sensitive to ethics and more ready to recognize the dilemmas they must face and then resolve.

c. Develop ethical competencies and expertise.

Expertise and competence about ethics for accountants is very important because it will strengthen its performance and will support its role as a professional. Learning about ethics provides an opportunity for someone to develop:

- Critical thinking about values that stimulates moral imagination and develops understanding of situations in order to make decisions.

- Expertise and competence of ethical considerations for someone to be able to make a judgment and responsible choice.

- One's empathy and appreciation for different social contexts and norms.

- Internalize the analysis system to deal with and manage ethical threats and dilemmas.
- Expertise in resolving conflicts that are important for establishing and maintaining an ethical framework in each individual and an ethical environment in the organization so that the ethical components become an integral part of decision making.

\section{d. Apply it to ethical behavior.}

Learning about ethics provides direction for individuals to respect all things about accounting ethics and prepare someone to deal with complicated situations in their lives.

By learning ethics and making efforts such as getting used to thinking, evaluating, and analyzing someone can develop a consensus on moral standards that can be applied consistently in society. In accordance with the results of IFAC (2006) research it was found that learning about ethics in business and accounting would be useful for:

a. Develop a sense of ethical responsibility towards the future of accountants.

b. Improve moral standards and attitudes of accountants in the future.

c. Floating problem solving skills that have ethical implications.

d. Develop a sense of professional responsibility

For this phenomenon Nasibulina (2015), Haynes (2016) state that academics and practitioners alike have responsibilities in developing ethics. The responsibility for learning about ethics cannot only involve academics, but practitioners can also play a positive role in this field. They have more diverse experiences and perspectives on developing issues and practical ethical trends that occur in the work environment in relation to the profession.

\section{Perspective of Accounting Education Institutions}

\subsection{The Role of the Curriculum on the Effectiveness of Learning about Ethics in Accounting Education}

According to Blanthorne et al. (2007), Liu et al. (2012) studies on learning about ethics in the accounting curriculum have revolved around the following questions: 1) should ethics be taught? 2) why is ethics taught/not taught? 3) who should teach ethics? 4) what should be taught? 5) where should ethics be taught? 6) how/what method is used to teach ethics? 7) Is the scope of learning about ethics currently fulfilling enough? Based on these questions, then Blanthorne et al. (2007) conducted research on this subject with the aim of updating previous research conducted by showing a broader and more comprehensive view of ethical education in accounting with accounting teaching staff as respondents of the study. In general, the results of his research show that respondents viewed the effectiveness of learning about ethics as determined by their institutions.

Institutions have the responsibility to facilitate their 
students by providing opportunities to develop two competencies namely ethical and technical competencies. Technical competence itself will not be effective in realizing ethics into practice if it is not accompanied by awareness and expertise to regulate different contexts. So that educational programs must consider learning contextual factors such as values, ethics and professional attitudes (IFAC, 2006). In addition, the results of the Blanthorne et al. (2007) show that factors such as time, material, knowledge or appreciation may be factors that can reduce the effectiveness of uniting ethics into the curriculum.

Not apart from the problems of the effectiveness of learning about ethics in the accounting curriculum mentioned above, Fisher and Swanson (2005) in Blanthorne et al. (2007) recommend five goals for learning about ethics in accounting, namely as follows:

a. Prepare a branch of ethical science that is consistent with the mission of the university.

b. Ensure that students develop a facility to use ethical language.

c. Facilitating students to be sensitive to ethical issues.

d. Improve students' ethical consideration skills.

e. Prepare a moral area for students in practice in a real workplace later.

Bean and Bernardi (2007) state that the best framework for a business ethics course or accounting ethics course is carried out in stages at the beginning of the year or second-year students. Furthermore, they believe that a specific gradual learning in "accounting ethics" is important for students entering the accounting profession. Such learning needs to focus on dealing with ethical issues as a basis for the professionalism of accountants.

Development and Specialization The stages of the Ethics Education Framework according to IFAC (2006) are as follows:

\section{a. Stage 1; Ethical Knowledge.}

Stage 1 is the foundation stage that strengthens the fundamental knowledge possessed by accounting members on issues related to values, ethics and professional attitudes. Ethics education at this stage focuses on the nature of ethics, the ethical framework for understanding the environment, theories and principles of ethics, kindness and moral development of a person.

\section{b. Stage 2; Ethical Sensitivity.}

In this stage basic ethical principles are introduced which are introduced in stage 1 to relevant relevant areas (eg auditing and taxation) in accounting practices. The purpose of stage 2 is to make accountants sensitive to the ethical dimensions of accounting practices, this is done to ensure that accountants are able to reorganize ethical threats when they arise.

\section{c. Stage 3; Ethical Assessment}

Stage 3 is the stage of application where someone learns how to unite and apply knowledge and ethical sensitivity to arrive at good and reasonable decisions. Stage 3 is structured to help accountants in deciding their ethical priorities and making accountants able to apply good processes in making ethical decisions.

\section{d. Stage 4; Ethical Behavior}

Stage 4 relates to how to behave ethically in every situation or contextual environment, such as a workplace. Ethical behavior means acting on principles, not just believing in principles. Therefore professional accountants have the responsibility to act something right.

Regarding learning about ethics, ethical intervention is a deliberately planned effort to promote the development of moral judgment. There are two forms of this intervention, namely; "Separate methods" are ethical interventions that address ethical issues in selected classes, and "recharge methods" namely ethical interventions that incorporate ethical issues into several accounting classes (Thomphson et al, 1992 and Schoenfieldt et al., 1991 in IFAC, 2006). This indicates that curriculum policies by educational institutions play an important role in the effectiveness of learning ethics in accounting education.

\subsection{The Role of Learning Facilities Against the Effectiveness of Learning Ethics in Accounting Education}

Sugahara and Watty (2016) conducted research on the quality of accounting education in Australia with academics as respondents. Watty (2005) uses several quality elements including 5 (five) quality elements to be applied in the context of accounting education in higher education. Five categories or definitions of quality are briefly defined as follows:

a. Exception. Alone, realizing good quality, exceeding standards.

b. Perfection. There are no shortcomings, take good actions (focus on processes such as input and output).

c. Fitness for purpose. The quality relationship for a destination is determined by the provider.

d. Value for money. Focus on efficiency and effectiveness, measuring output and input.

e. Transformation. An opportunity; education that is giving something to students, different from giving something to consumers: including the concept of enhancing and empowering: democracy in the process, not just in results.

An important result of the Watty study is that the view of quality is not in evaluating the results, but emphasizes the transformation process, where the transformation process can be effective if one is supported by the availability of adequate facilities to support the learning process.

Regarding the existence of facilities in accounting education, the Accounting Education Change Commission (AECC) has recommended the use of information 
technology in conducting accounting learning, including continuing to keep up with the latest developments in the field of technology. This is needed so that accounting learning can always be developed, students can have challenges to think, and give them media to solve problems correctly, effectively and efficiently" (AECC, 1993 in Murphy and Hoeppner, 2002). No exception to learning about ethics, mastery or information technology skills also strongly support the effectiveness of learning about ethics. Accounting practitioners and academics agree that the skills needed to succeed in today's global development environment are communication, analytical skills and problem solving skills, teamwork, intelligence shown in computer technology, and effective business decision-making skills (Murphy and Hoeppner, 2002). Likewise accounting professionals, they argue that there are no skills that are more important than the ability to examine data and solve a problem experienced by clients or employers effectively and efficiently by utilizing information technology that is currently developing, so that even new workers required to have skills in the field of information technology and be able to utilize information technology to facilitate their work in accounting (Murphy and Hoeppner, 2002). This indicates that when the effectiveness of learning about ethics is measured by students' ethical behavior and determining ethical decisions in carrying out accounting functions where the existence of facilities can play an important role in supporting the effectiveness of learning about ethics in accounting education.

\section{Perspective of Accounting Educators}

Bean and Bernardi (2007) stated that learning about ethics in accounting education must be taught by accounting educators. This is supported by Sims (2000) stating that "philosophers do not always have experience, or background understanding of business to convince students. Boyce (2008) states that accounting education institutions need to provide opportunities for educators to be critical in teaching and contribute to efforts to increase students' ethical awareness, so that educators can increase their commitment to social change in teaching ethics in accounting, of course, starting from providing an understanding of accounting functions, ethical issues and connecting between the implementation of accounting functions and ethical behavior.

In this regard, Beauvais et al. (2007) tried to conduct research to examine how the perceptions and attitudes of educators after observing the unethical behavior of their colleagues and students in 3 different educational institutions over a period of 4 years. The results of his research indicate that increased publicity regarding unethical actions carried out by the company and their observations of unethical behavior shown by their colleagues and students makes educators more sensitive to ethical problems, and this impacts their perceptions of the importance of learning. ethics is increasing. On the basis of this explanation it can be said that if educators argue that learning about ethics is very important in the world of business and accounting, then learning about ethics will be more effective, on the contrary if educators assume that learning about ethics is not important in the world of business and accounting, learning about ethics will not be effective do. This indicates that to make learning ethics effective in accounting education it must involve educators from the accounting department itself and will be influenced by the perceptions of educators on the importance of learning about ethics in business and accounting.

Moral education is a lifelong process, which is why ethics training in sustainable education is needed to ensure the development of sustainable moral considerations (Shenkir, 1990, in IFAC, 2006). Ethics learning can be done using two types of approaches, namely ethics can be taught as a general subject and emphasizes the philosophy of critical evaluation, without considering education related to the profession. In addition, ethics can also be taught as an applied class that focuses exclusively on moral issues that arise in the profession.

General ethics lessons are based on two assumptions, namely: first is to determine how a person should behave based on religion, philosophical principles and ethical norms. Second, a descriptive analysis or contextual factors that explain the processes that influence a behavior. General ethics classes are usually taught by ethics experts. Ethics taught by ethics are usually based on philosophical perspectives rather than based on practice and professional level. However, in reality students who study in general ethical studies feel frustrated because of the lack of a relationship between ethics discussed with existing business practices. Such an approach will provide responsibility to students only to combine ethical theory with management and business, where students may fail to capture the relationship between ethical views in a philosophical and practical situation that arises in the business world, so that if learning about ethics in accounting rests only on philosophical principles, it will be difficult to get enough expertise to help business managers or professional accountants in dealing with ethical dilemmas.

Another option that can be used is ethics taught by business educators or accounting educators. Because this is based on the existence of people outside the ethics expert who are able to develop and successfully teach ethics, which their success begins with an understanding of the discipline of knowledge, so it can be said that the credibility of someone teaching ethics can actually be strengthened by personal knowledge of an educator or certain experiences about problems related to their profession. However, the problem often found is that 
business educators and accounting do not have enough training to teach ethics correctly (Beauvais, et al. 2007) that clearly creates various implications, which lack of training will result in educators avoiding ethical subjects in their classrooms., or only discuss the ethical subject of the outer skin.

The same opinion was issued by Sims and Felton (2006), Hess and McAvoy (2014), IFAC (2006) who say that business educators feel uncomfortable to discuss ethical issues in the classroom. In situations like this, educators may have to concentrate on other material aspects that are felt comfortable to teach (Mintz, 2016)). The results of the IFAC (2006) state that most educators are considered an example by their students. Therefore some respondents suggested educators, philosophers and other experts to consider additional sources of ethical classes that could include both conceptual knowledge and the subject matter being applied. In line with this, Armstrong, et al (2003) claim that changing ethical behavior may be beyond the ability of accounting educators. But educators can help change behavior by increasing moral sensitivity, moral judgment and moral encouragement. By attending training on ethics, educators will be more prepared and comfortable to teach ethics. With these preparations, educators will always include ethical topics in any subject learning and they will always take the time to discuss the ethics (Beauvais et al. 2007), so that it can be concluded that ethical training is followed by accounting educators will play an important role in effective learning ethics in accounting education.

\section{Accounting Student Perspective}

An American psychologist named James Rest conducted a long research on moral development in the early 1980s. James found that there were very dramatic changes in young people and adults in the scope of problem solving strategies related to ethical issues and this was closely related to the length of formal learning time from those in school (IFAC, 2006). Moral assessment will continue to develop during the period of education and will stagnate when the education stops. The result of research by Shapiro and Stefkovich (2016) found that the level of education has been tested as a factor that influences the development of perspectives on ethics. On the basis of this matter, it can be concluded that student study experience can play an important role in realizing the effectiveness of learning about ethics in accounting education.Crossman (2017) examined the relationship between the performance of early-level accounting graduates and previous work experience in accounting and student study experience. The results indicate that the academic background in accounting, after being combined with relevant work experience, provides better support for the success of accounting graduates in carrying out their obligations.
Regarding ethical behavior, it was also found that differences in a person's ethical behavior were related to their level of education, gender, and work experience (Dhar, 2016), and this also supported the empirical results shown by Keller et al. (2007). The results indicate that there are differences in individual ethical standards based on gender, education level (alumni vs. students who have not graduated), obedience to religion, and work experience.

Work experience and education level have a greater impact on ethical decision-making processes, which are related to learning about ethics, Keller, et al. stressed that although for most students, religious principles play a fundamental role in forming ethical standards, but students who have some work experience will be more concerned and concerned about a conflict that occurs between ethical standards and place operational standards. where they work, because they have clearly seen how these ethical standards are violated, so what happens is that those who have work experience sometimes consider students who do not have too idealistic or naive work experience. Based on this reality, it can be concluded that student work experience influences the effectiveness of learning about ethics in accounting education.

According to Everaert et al. (2017) intrinsic motivation is related to one's efforts to develop themselves or to obtain good learning values, while extrinsic motivation is related to the goal of improving his career in the future. Regarding someone's motivation to study, the results of Halabi (2009) study found that someone who is older will have extrinsic motivation that is greater than his intrinsic motivation. Learning ethics and developing it is a long process and is a training process to gain knowledge, apply appropriate principles in a constantly changing context, sharpen and focus the goals of the individual and reflect the actions and responses of the individual. Regarding the perception of the importance of learning about ethics, in accounting, based on the results of Byrne et al. (2012) found that the perceptions of accounting students towards the importance of learning about ethics in accounting education were influenced by the expectations of their future work or their extrinsic motivation, which would then influence students' understanding of learning about ethics. This shows that students' extrinsic motivation influences the effectiveness of learning about ethics in accounting.

\section{Learning Method for the Effectiveness of Learning Ethics in Accounting Education}

For the previous discussion, it can be concluded that the effectiveness of learning ethics in accounting education is largely determined by the role of educational institutions, educators and accounting students themselves. Each of these parties plays a very important role in effective learning of ethics, because with curriculum factors, 
learning facilities, perceptions and training of educators and study experience, work experience and extrinsic motivation of students, both educational institutions, educators and students have their respective roles are interrelated with each other. For this reason, synergy of the parties concerned is needed so that learning about ethics in accounting can achieve its objectives and be able to create accountants who behave ethically and uphold ethical values in carrying out accounting functions. Regarding accounting education in Indonesia, Furqan (2009) states that in order for the accounting education process to improve graduates 'competencies, learning methods play an important role in mediating the influence of students' initial knowledge and educational technology on student competencies, so that student potential can be developed, the curriculum can achieving its objectives and learning facilities can be utilized optimally in the achievement of the objectives of accounting education, it must be supported by the determination of learning methods appropriately in each subject taught, including ethics learning. However, there are several issues that are still a matter of debate among practitioners and academics regarding learning about ethics.

The process of making ethical decisions is not an easy matter. The inability to provide satisfying moral conclusions can make students feel confused, because sometimes questions about morality cannot be answered, it causes cynical behavior towards ethics. There are claims that assume that ethics are too abstract to be communicated to students. This problem of ambiguity is present in many classes and it is not restricted to ethical classes only. This issue of ambiguity reinforces the need for students to evaluate training with the aim of a clear understanding of the problem by identifying key elements that experience dilemmas and predictions of possible outcomes (Earl, 2012). By learning to analyze ethical dilemmas, students will realize that each dilemma must have a solution. Although the ethical analysis cannot provide a truly correct answer, at least it can provide answers that can clearly be seen as something that is more suitable or better than the other answers.

The ability of students to conduct an analysis of ethical problems is largely determined by how learning about ethics is done. In the Framework for International Education Statements (IFAC, 2005) it is stated that Learning refers to the main processes of individuals in gaining ability. (professional knowledge, professional expertise, professional values, ethics, and attitude). Learning can be formal and systematic or informal and not systematic. When individuals go through a systematic process, that is what is called education. Learning is a process in which an activity originates or changes through the reaction of a situation at hand, with the condition that the characteristics of the change in activity cannot be explained on the basis of trends the tendency of the original reaction, maturity, or temporary changes of the organism. So that it can be said that learning occurs when changes occur due to an event or reaction from the situation that occurs.

Learning should involve two things, namely involving not only the brain to think but also having to involve the heart to feel it. Or in other words learning should involve cognitive aspects (brain) and affective aspects (heart). Cognitive goals can be grouped into: knowledge, understanding, application, analysis, synthesis and evaluation. While the affective aspects have a goal so that both students and lecturers can use their hearts in the learning process. Learning does not only emphasize what is taught but also how to teach it. In order to achieve the goals of learning it is necessary to use the right learning method. Not all learning methods are right for all times, conditions and fields. In general, learning methods can be divided into passive methods and active methods. The passive method is a one-way learning method from lecturers to students while the active method encourages students to actively discuss in class.

The conventional lecture method is more directed at a transfer of knowledge rather than as a learning process. In accounting education, this method is not suitable for developing a person's ability to solve the mechanism of procedural problems and is also considered unsuitable for developing complex ethical problem solving abilities (IFAC, 2006), so that learning about ethics methods that are considered most suitable are collaborative learning methods that emphasizing leadership, decision making, trust building, communication management and conflict, or in the form of case studies, literature studies and role playing. These methods can lead to involvement that links students to problems and provides views on how it feels to experience such problems. In addition to the collaborative method above, accounting educators should also explore and look for newer methods in delivering learning about ethics to accounting education. The method can be developed by training in articles about personality values, work placements and bringing in guest speakers from practitioners.

In addition, the development of learning about ethics methods coupled with more optimal use of the availability of learning facilities and appropriate curriculum support can lead to more effective learning about ethics in creating awareness of accounting students so that they can behave ethically and carry out accounting functions appropriately and ethically. Moreover, if the ethics learning method is interspersed with discussion of cases and involving practitioners in it, surely it can open more discourse of students and accounting educators in understanding the actual issues that are developing and the tendency for ethical practices related to the accounting profession and occurs in the work environment when this.

Therefore, departing from the accounting education model developed by Frederickson and Pratt (1995) in 
identifying the objectives of accounting education and the mechanisms to obtain it, specifically in order to optimize the competence of accounting graduates in accordance with employment needs as follows:

Minimize Cd-Cs $=\mathrm{f}(\mathrm{AR}, \mathrm{Cur}, \mathrm{CC}, \mathrm{IM})$

Subject to S, F, I

Where: $\mathrm{Cd}=$ Competencies demanded; $\mathrm{Cs}=$ Competencies supplied; $\mathrm{AR}=\mathrm{Admission}$ and recruitment; Cur = Curriculum; $\mathrm{CC}=$ Course content; $\mathrm{IM}=$ Instructional methods; $\mathrm{S}=$ Student Ability and effort; $\mathrm{F}=$ Faculty Ability and effort; I = Institutional resources provided for education.

As well as the results of Furqan (2009) research that found the mediating role of learning methods in increasing the influence of students 'initial knowledge and educational technology on the competence of accounting education graduates, there is a need for practitioners' involvement in learning ethics (Bean and Bernardi, 2007), and in order to achieve the objectives of learning about ethics in business education (as IFAC, 2006) an ethical education model is needed that can shape student perceptions about the importance of ethical behavior in carrying out accounting functions, so that they can think critically before making decisions that have ethical implications.

The ethics education model in the world of accounting education in question is the creation of an appropriate ethics learning method, and is based on the collaboration between the role of accounting education institutions in preparing curriculum and facilities, the role of accounting educators (academics) for their experiences in attending ethics training and their perception of learning ethics, the role of practitioners in their experiences and perspectives on real conditions and issues developing in the world of work and the role of students themselves in their study experience, intrinsic motivation and work experience. This can be illustrated as follows:

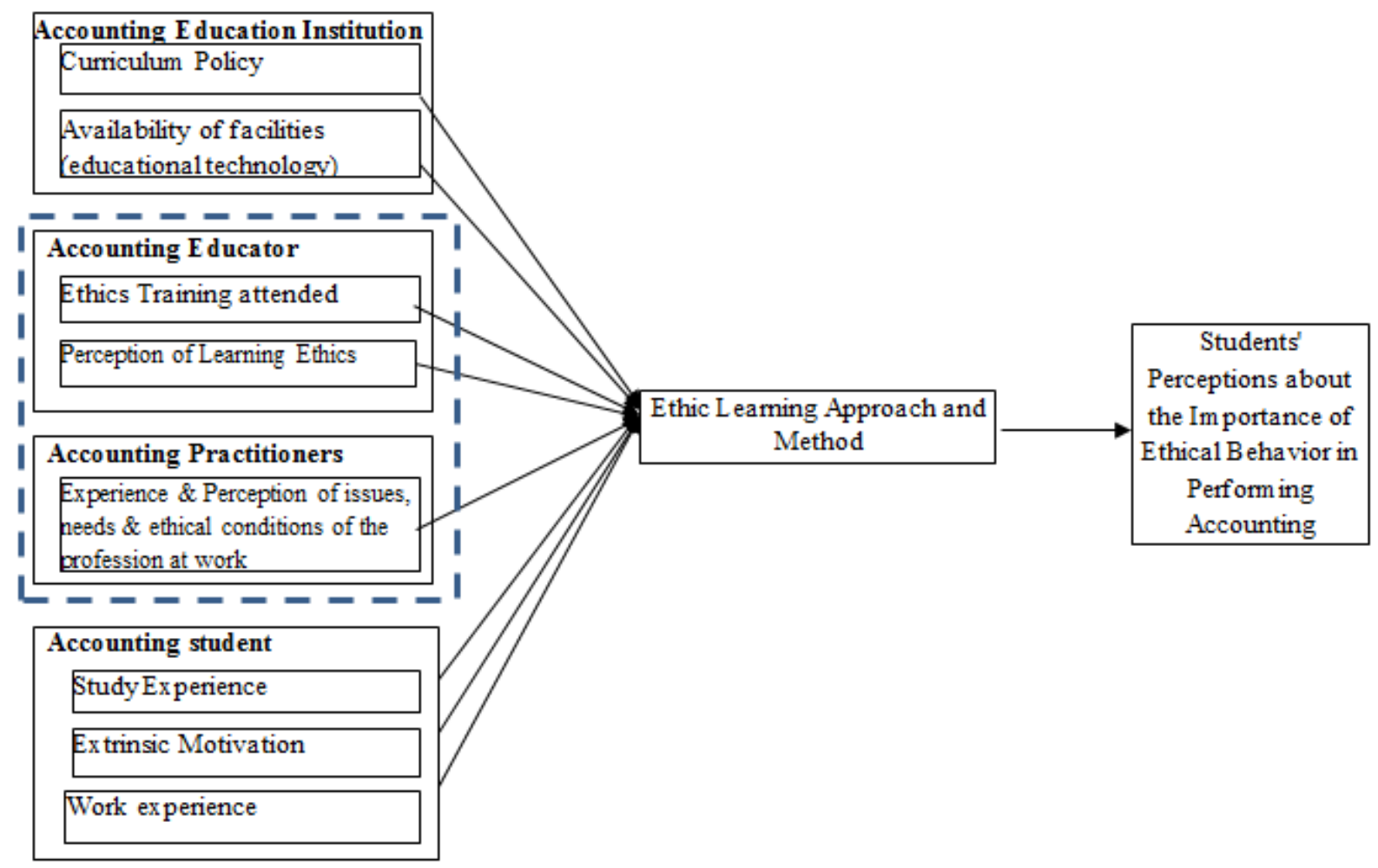

Figure 1. Model of Learning about Ethics in Accounting Education 
Figure 1 showed that the method of ethics learning becomes an important factor and determinant of the effectiveness of learning about ethics in accounting education, where the effectiveness of learning about ethics is characterized by how much students' perceptions of the importance of ethical behavior in carrying out accounting functions. When students form a perception that ethics is a very basic thing in carrying out accounting functions, this is expected to form accounting graduates who have values, ethics and professional attitudes in carrying out accounting functions, as well as being an indicator of the effectiveness of learning ethics.

Meanwhile, the position of the learning method as a mediator of the effectiveness of learning about ethics because the ethics learning method is a container of interaction between educators (including involving practitioners) and students facilitated by educational institutions. The accuracy of the use of learning methods by educators needs to get support from educational institutions with adequate curriculum and facilities (especially with the rapid development of educational technology at this time). Likewise with the accuracy of educators determine the method of learning, is largely determined by their experiences and perceptions of ethical behavior. Educators who have training experience on ethics will better understand the various methods that can be used in every class meeting, so they can use more appropriate learning methods. On the other hand, although students have a lot of study experience and work experience and great extrinsic motivation, when transferring knowledge is not carried out with appropriate learning methods, it can cause students to not be able to find the urgency of learning about ethics, and not to make ethics as a factor which is important in supporting the effective implementation of accounting functions.

\section{Model of Stakeholder Convergence in Learning about Ethics in Accounting Education: Indonesian Perspective}

Specifically in Indonesia, according to Baridwan (1996), Accounting education in Indonesia both at the tertiary level and vocational high school is highly colored by the Anglo Saxon system (Baridwan, 1996). In addition to academic education, there are also vocational, professional and non-formal education courses that can be taken in accounting education. The existence of accounting education has begun from high school. In the General High School, accounting education is given in outline or only limited to the basics of accounting, whereas in Vocational High Schools especially in accounting, accounting education is given more in depth, so that graduates can enter the workforce as bookkeepers ( bookkeeper) or accounting technician (Accounting Technition). In ensuring the quality of every individual who has completed his studies at the Vocational School, a certification or competency test is conducted on each Vocational School graduate, so that he is able to compete and be absorbed in the world of work.

After going through secondary education both high school and vocational school, accounting education can be continued at the level of tertiary education (tertiary). According to Law No. 20 of 2003 concerning the National Education System, higher education is divided into two, namely vocational education and academic education. Vocational education programs (diplomas) are held so that students can have jobs with certain applied skills. While academic education is higher education that is directed primarily at the acquisition and development of certain scientific, technological disciplines, which include undergraduate (S1), postgraduate (S2) and doctoral (S3) programs. Accounting education in the undergraduate program (S1) is directed to produce competent personnel to carry out accounting tasks and work both in private and government agencies which can then become the basis for attending S2 and S3 education or can be the basis for attending accounting professional education. For the S2 program, accounting education is directed at a combination of practical and conceptual aspects of accounting science in accordance with the latest developments and by paying attention to the need for accounting knowledge in accordance with the profession they are undergoing, while for the $\mathrm{S} 3$ program, accounting education is more directed to the mastery of accounting knowledge the latest both theories, approaches, methods and rules of accounting science through research and sharpness of reasoning that are expected to contribute to the development of accounting science and to society, nation and state.

In connection with the implementation of the accounting profession education, at this stage accounting education is held to prepare staff who have the requirements of accounting professionalism skills so that they are competent to enter certain accounting professions. Accounting profession education is not an obligation but an option, so this should only be taken if accounting graduates from educational institutions majoring in accounting choose to become accountants. The organization of accounting professional education in Indonesia is based on the Minister of Finance Regulation (PMK) Number 25/PMK.01/2014 concerning State Registered Accountants and the Republic of Indonesia Minister of Education and Culture Regulation Number 153 of 2014 concerning the Implementation of the Professional Accountant Program Education.

Meanwhile, related to the accounting profession certification in Indonesia, professional accounting institutions in Indonesia, such as the Indonesian Institute of Accountants (IAI), the Indonesian Institute of Certified Public Accountants (IAPI) and the Indonesian Institute of Management Accountants (IAMI) have held various 
certifications for accountants/non accountants in Indonesia, including the Government Accounting Expert Certification Exam (USAAP), the Sharia Accounting Certification Test (USAS), the Basic Skills Certification Test (USKAD), the Financial Accounting Standards Statement Certification (USPSAK), Certified Professional Management Accountant (CPMA) and Certified Public Accountant of Indonesia, (CPA of Indonesia/CPA). This certification is not the end of accounting education in Indonesia, after obtaining an accountant's degree and/or certification, each accountant and certification holder must still be demanded to always maintain and improve his competence through continuing education through seminars, courses and trainings.

In practice, learning ethics in accounting education in Indonesia is only included in the curriculum at the level of vocational education, academic education and professional education and continuing education. However, there is no standard reference (standardization) related to curriculum, course content, implementation time (level/semester to what) and ethics learning methods that are uniform and used as a reference for accounting education institutions in Indonesia, including those stipulated by professional accounting institution. This resulted in the implementation of learning about ethics at each level of education is different in each educational institution, because it can not be separated from the policies of each educational institution.

Meanwhile, professional education institutions in Indonesia found need to align the quality and quality of undergraduate in accounting, accountants \& professional accountants throughout Indonesia, standardization in the accounting profession education is needed, especially related standards with graduate competencies, assessment methods, acceptance requirements, ownership of educational technology and learning methods. Therefore, to achieve the objectives of ethics learning in accounting education and the creation of ethical perceptions and behaviors that are appropriate for graduates of accounting education, accountants \& professional accountants in carrying out accounting functions in the world of work, it is necessary to standardize learning about ethics models in all types/levels accounting education in Indonesia, starting from secondary education to continuing education in accounting, which standardization is specifically related to the role of educational institutions and the role of accounting educators (academics) based on the needs and conditions of the workforce as well as the professional code of ethics established by the institution accounting profession. The linkages between all parties (stakeholders) involved in the formation of an learning about ethics model at each level/type of accounting education that is expected to exist in Indonesia can be seen in Figure 2.

Figure 2 shows that both internal education stakeholders (educational institutions \& accounting educators) and external education stakeholders (the World of Work \& Professional Accounting Institutions) have their respective roles in shaping learning about ethics models in accounting education, so collaboration between them is crucial in creating learning about ethics models that are appropriate and in accordance with the needs of the workforce today and the formation of perceptions and ethical behavior for Graduates (Bachelor) in Accounting, Accountants \& Professional Accountants (Certification Holders).

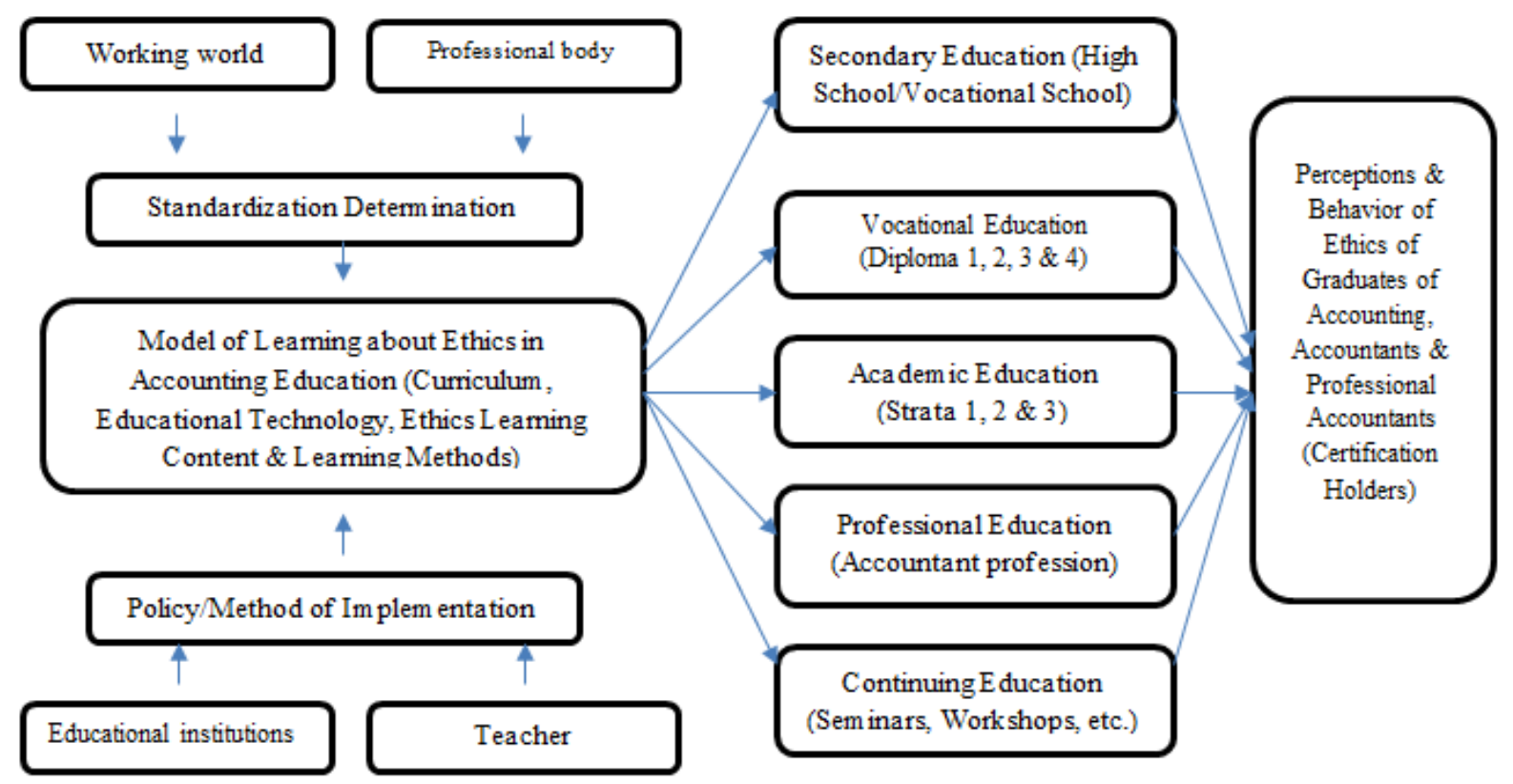

Figure 2. Stakeholder Convergence Model in the Formation of Ethics Learning Model in Accordance with the Type/Level of Accounting Education in Indonesia 
Of course, if this is based on the purpose of holding ethics learning in accounting education as formulated in IFAC (2006) then to establish an intellectual foundation in understanding ethical position, developing ethical sensitivity, developing ethical competence and expertise and applying ethical behavior for graduates of Accounting education, Accountants \& Professional Accountants (Certification Holders), collaboration between all relevant stakeholders is needed, especially in order to determine the appropriate learning about ethics methods. However, as happened in Indonesia, with various types/levels of accounting education, there are differences in perceptions, policies and methods of implementing educational institutions and educators, there are differences in conditions/demands of the world of work and regulations/codes of ethics established by professional institutions in each region then to realize the stakeholder convergence model in accounting education as stipulated in IFAC, it is necessary to study more deeply the extent of the influence of supporting factors for the creation of an learning about ethics model in accounting education that is appropriate and in accordance with the conditions/needs of the world of work in each region and the role of each stakeholder in it.

\section{Conclusions}

Professional values, ethics and attitudes in accounting are behaviors and characteristics of professionals who can identify professional accountants as part of members of the profession, including actions that are associated with ethical principles that are considered important in defining different professional behavioral characteristics and commitment to technical competence, ethical behavior, professional attitude, self-development efforts, and social responsibility. To make it happen, at the education level, learning about ethics must be carried out effectively.

The effectiveness of learning about ethics in accounting is characterized by how much students perceive the importance of ethical behavior, so that it can influence their behavior in carrying out accounting functions responsibly and professionally in society. To streamline learning ethics is inseparable from the participation of educational institutions, educators and students themselves. Educational institutions must determine the curriculum and provide adequate facilities to support the implementation of learning about ethics, educators are required to expand their knowledge and skills in order to conduct learning about ethics appropriately, while in learning ethics students will be greatly influenced by their prior knowledge, work experience and motivation their extrinsic. Because the effectiveness of learning about ethics is largely determined by educational institutions, educators and accounting students, therefore, so that learning about ethics can be effective and students find the urgency of learning about ethics in accounting, learning about ethics methods play an important role in determining its success.

Based on the results of this study, if it is associated with the role of Accountants in eradicating corruption, to create accountants who can play an active role in eradicating corruption in the midst of the current corruption practices in Indonesia, it must begin with improvements in the world of accounting education. Accounting education must always be directed to produce accountants who are professional, competent and ethical, so that they can benefit their profession and society. In order to realize the effectiveness of learning about ethics that is then for educational institutions, educators, students and for professional organizations.

Based on the literature, learning about ethics in accounting is strongly influenced by accounting education institutions, accounting educators and accounting students, so that to overcome the limitations of this study which only uses literature studies, further research related to learning about ethics in accounting education can be done by further searching the involvement of related parties is good by using quantitative and other qualitative research methods.

\section{REFERENCES}

[1] Aristotle, C. (2006). Nicomachean ethics. Read How You Want. com.

[2] Baridwan, Z. (1996). Strategi Pendidikan Akuntansi Menjelang Abad XXI. Jurnal Akuntansi \& Manajemen

[3] Beauvais, L. L., Desplaces, D. E., Melchar, D. E., \& Bosco, S. M. (2007). Business faculty perceptions and actions regarding ethics education. Journal of Academic Ethics, 5(1), 121-136.

[4] Boyce, G. (2008). The social relevance of ethics education in a global (ising) era: From individual dilemmas to systemic crises. Critical Perspectives on Accounting, 19(2), 255-290.

[5] Byrne, M., Flood, B., Hassall, T., Joyce, J., Arquero Montaño, J. L., González González, J. M., \& Tourna-Germanou, E. (2012, June). Motivations, expectations and preparedness for higher education: A study of accounting students in Ireland, the UK, Spain and Greece. In Accounting Forum (Vol. 36, No. 2, pp. 134-144). Taylor \& Francis.

[6] Crossman, H. A. (2017). Awareness of the public versus private accounting divide, and its impact on the career path preference of accounting students. Accounting Education, 26(4), 392-409.

[7] Dhar, R. L. (2016). Ethical leadership and its impact on service innovative behavior: The role of LMX and job autonomy. Tourism Management, 57, 139-148.

[8] Earl, L. M. (2012). Assessment as learning: Using classroom assessment to maximize student learning. Corwin Press.

[9] Everaert, P., Opdecam, E., \& Maussen, S. (2017). The 
relationship between motivation, learning approaches, academic performance and time spent. Accounting Education, 26(1), 78-107.

[10] Fakhimuddin, M. (2018). Reconsidering Accounting Information Systems: Effective Formulations for Company's Internal Control. Arthatama Journal of Business Management and Accounting, 2(1).

[11] Frederickson, J. R., \& Pratt, J. (1995). A model of the accounting education process. Issues in Accounting Education, 10(2), 229

[12] Fernández Fernández, J. L., \& Sanjuán, A. B. (2010). The presence of Business ethics and CSR in the higher education curricula for executives: the case of Spain. Journal of Business Ethics Education, 7, 25-38.

[13] Fiolleau, K., \& Kaplan, S. E. (2017). Recognizing ethical issues: An examination of practicing industry accountants and accounting students. Journal of Business Ethics, 142(2), $259-276$

[14] Furqan, A. C. (2009). Metoda intruksional sebagai pemediasi pengaruh persyaratan penerimaan dan teknologi pendidikan terhadap kompetensi lulusan pendidikan akuntansi di Indonesia (Doctoral dissertation, Universitas Gadjah Mada).

[15] Gaviria, D., Arango, J., \& Valencia, A. (2015). Reflections about the use of information and communication technologies in accounting education. Procedia-Social and Behavioral Sciences, 176, 992-997.

[16] Halabi, A. (2009). Empirical evidence examining the academic performance of students in the first two accounting subjects. Asian Review of Accounting, 17(1), $77-88$.

[17] Haynes, F. (2016). Ethics and education. Encyclopedia of Educational Philosophy and Theory, 1-5.

[18] Hess, D. E., \& McAvoy, P. (2014). The political classroom: Evidence and ethics in democratic education. Routledge.

[19] International Federation of Accountants/IFAC. (2006). Approaches to the Development and Maintenance of Professional Values, Ethics and Attitudes in Accounting Education Programs

[20] International Federation of Accountants/IFAC. (2005). International Education Standards for Professional Accountants (IESs).

[21] Jonson, E. P., McGuire, L., \& Cooper, B. (2016). Does teaching ethics do any good? Education+ Training, 58(4), $439-454$.

[22] Keller, A. C., Smith, K. T., \& Smith, L. M. (2007). Do gender, educational level, religiosity, and work experience affect the ethical decision-making of US accountants? Critical perspectives on accounting, 18(3), 299-314.

[23] Kohlberg, L. (1981). Essays on moral development (Vol. 1, pp. 409-412). San Francisco: Harper \& Row.

[24] Lai, K. W., \& Hong, K. S. (2015). Technology use and learning characteristics of students in higher education: Do generational differences exist? British Journal of Educational Technology, 46(4), 725-738.

[25] Lawson, R. A., Blocher, E. J., Brewer, P. C., Morris, J. T.,
Stocks, K. D., Sorensen, J. E.,... \& Wouters, M. J. (2015). Thoughts on competency integration in accounting education. Issues in Accounting Education, 30(3), 149-171.

[26] Liu, C., Yao, L. J., \& Hu, N. (2012). Improving ethics education in accounting: Lessons from medicine and law. Issues in Accounting Education, 27(3), 671-690.

[27] Martinov-Bennie, N., \& Mladenovic, R. (2015). Investigation of the impact of an ethical framework and an integrated ethics education on accounting students' ethical sensitivity and judgment. Journal of Business Ethics, 127(1), 189-203.

[28] Mintz, S. (2016). Giving voice to values: A new approach to accounting ethics education. Global Perspectives on Accounting Education, 13(1), 37-50.

[29] Mladenovic, R., Martinov-Bennie, N., \& Bell, A. (2019). Business students' insights into their development of ethical decision-making. Journal of Business Ethics, 155(1), 275-287.

[30] Mohd Ghazali, N. A. (2015). The influence of a business ethics course on ethical judgments of Malaysian accountants. Journal of Asia Business Studies, 9(2), 147-161.

[31] Murphy, E. A., \& Hoeppner, C. J. (2002). Using technology and library resources in financial accounting courses. Journal of Accounting Education, 20(4), 331-346.

[32] Nasibulina, A. (2015). Education for sustainable development and environmental ethics. Procedia-Social and Behavioral Sciences, 214, 1077-1082.

[33] Pan, G., \& Seow, P. S. (2016). Preparing accounting graduates for digital revolution: A critical review of information technology competencies and skills development. Journal of Education for business, 91(3), 166-175.

[34] Ritter, B. A. (2006). Can business ethics be trained? A study of the ethical decision-making process in business students. Journal of Business Ethics, 68(2), 153-164.

[35] Rutherford, M. A., Parks, L., Cavazos, D. E., \& White, C. D. (2012). Business ethics as a required course: Investigating the factors impacting the decision to require ethics in the undergraduate business core curriculum. Academy of Management Learning \& Education, 11(2), 174-186.

[36] Salam, B. (2000). Etika Individual, Pola Dasar Filsafat Moral. Jakarta: Rineka Cipta.

[37] Sauser Jr, W. I., \& Sims, R. R. (2018). Showing business students how to contribute to organizational cultures grounded in moral character. In Business Education and Ethics: Concepts, Methodologies, Tools, and Applications (pp. 485-507). IGI Global.

[38] Seele, P. (2016). Business ethics without philosophers? Evidence for and implications of the shift from applied philosophers to business scholars on the editorial boards of business ethics journals. Metaphilosophy, 47(1), 75-91.

[39] Sekaran, U., \& Bougie, R. (2016). Research methods for business: A skill building approach. John Wiley \& Sons.

[40] Shapiro, J. P., \& Stefkovich, J. A. (2016). Ethical leadership and decision making in education: Applying theoretical 
perspectives to complex dilemmas. Routledge.

[41] Shawver, T. J., \& Miller, W. F. (2017). Moral intensity revisited: Measuring the benefit of accounting ethics interventions. Journal of business ethics, 141(3), 587-603.

[42] Shawver, T. J., \& Miller, W. F. (2017). Moral intensity revisited: Measuring the benefit of accounting ethics interventions. Journal of business ethics, 141(3), 587-603.

[43] Sims, R. L. (2000). Teaching business ethics: A case study of an ethics across the curriculum policy. Teaching Business Ethics, 4(4), 437-443.

[44] Sims, R. R., \& Felton, E. L. (2006). Designing and delivering business ethics teaching and learning. Journal of Business Ethics, 63(3), 297-312.

[45] Sims, R. R., \& Sims, S. J. (1991). Increasing applied business ethics courses in business school curricula. Journal of Business Ethics, 10(3), 211-219.

[46] Sugahara, S., \& Watty, K. (2016). Global convergence of accounting education: An exploratory study of the perceptions of accounting academics in Australia and Japan. Asian Review of Accounting, 24(3), 254-273.

[47] Tormo-Carbó, G., Seguí-Mas, E., \& Oltra, V. (2016). Accounting ethics in unfriendly environments: The educational challenge. Journal of business ethics, 135(1), 161-175.

[48] Velliaris, D. M., Willis, C. R., \& Pierce, J. M. (2015). International student perceptions of ethics in a business pathway course. In New voices in higher education research and scholarship (pp. 232-250). IGI Global.

[49] Watty, K. (2005). Quality in accounting education: what say the academics?. Quality assurance in education, 13(2), $120-131$.

[50] Wright, N. S., \& Bennett, H. (2011). Business ethics, CSR, sustainability and the MBA. Journal of Management \& Organization, 17(5), 641-655.

[51] Wymer, W., \& Rundle-Thiele, S. R. (2017). Inclusion of ethics, social responsibility, and sustainability in business school curricula: a benchmark study. International Review on Public and Nonprofit Marketing, 14(1), 19-34. 